\title{
ANALYSIS OF CHARACTERISTICS OF A 5 KW POWER PLANT BASED ON SOLID OXIDE FUEL CELLS IN FOUR MODES
}

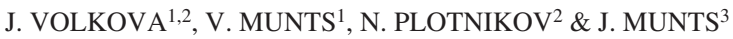 \\ ${ }^{1}$ Department of Heat Power Engineering and Heat Engineering, Ural Federal University, Russia. \\ ${ }^{2}$ Ural Industrial Company, Russia. \\ ${ }^{3}$ Department of Control Systems in Power Engineering and Production Plants, Ural Federal University, Russia.
}

\begin{abstract}
The paper presents the results of testing a $5 \mathrm{~kW}$ power plant based on solid oxide fuel cells (SOFC) with natural gas serving as fuel, equipped with a steam reformer combined with a burner. It includes a diagram of the power plant and a result analysis procedure based on heat and mass balances elaborated for the reformer, SOFC stack, catalytic burner and heat exchanger. The experimental findings were used to calculate the actual ratios of fuel utilization, oxygen consumption from cathode air in the electrochemical generator using two methods (heat and energy balances and Faraday's law). A comparison of the results of the two methods revealed a small error, which was observed mainly in the second mode $(60 \%)$.

Parameters of the power plant by 'UIC' LLC were reviewed at four steady running modes: $40 \%$ of SOFC's power utilization $(2 \mathrm{~kW}), 60 \%(3 \mathrm{~kW}), 90 \%(4.5 \mathrm{~kW})$ and at the peak mode of $110 \%(5.4 \mathrm{~kW})$, where the consumption exceeds the rated power by $10 \%$.

Calculation of the equilibrium composition of conversion products, at temperatures $\left(\mathrm{t}_{3}\right)$ registered at the reformer's outlet, allowed the formula for the natural gas reforming reaction to be obtained.

A simplified method of calculating the composition of the natural gas steam reforming products is described; the results are compared with calculations made in the program Gaseq, using the software package Mathcad for the solution of nonlinear equations.

Analysis of the results showed the effectiveness of a simplified method at temperatures above $800^{\circ} \mathrm{C}$; in that temperature range, this method has an error of less than $0.5 \%$, which is sufficient for using in practice.
\end{abstract}

Keywords: result of experiments, simplified method of calculating, solid oxide fuel cells, steam reforming of natural gas, studying of performance.

\section{INTRODUCTION}

The direct conversion of the energy from chemical reactions is implemented in fuel cells consisting of two electrodes with an electrolyte between them [1]. SOFC (solid oxide fuel cells) systems for the synthesis gas production use a well-known steam methane reforming method which is based on the reaction $\mathrm{CH}_{4}+\mathrm{H}_{2} \mathrm{O}=\mathrm{CO}+3 \mathrm{H}_{2}$ occurring in the Ni catalyst bed at high temperatures. SOFC systems with a steam reformer seem a more practical solution than those with an air reformer, as their efficiency can be improved by using the wastegas heat to maintain the required temperature of the reformer for the endothermic reaction. Besides, there is no nitrogen in the reformer and the anodic channel, which usually reduces the partial pressure of components. When leaving the anode, the gas, basically, consists of $\mathrm{CO}_{2}$ and $\mathrm{H}_{2} \mathrm{O}$, and it can also contain from $20 \%$ to $40 \%$ of unreacted $\mathrm{CO}$ and $\mathrm{H}_{2}$. Therefore, it is possible to completely burn such gas and utilize the resultant heat to reheat the reformer and the air supplied to the cathode. 


\section{TEST FACILITY LAYOUT}

Figure 1 shows the layout of a $5 \mathrm{~kW}$ SOFC-based power plant. The tests used natural gas, containing up to $0.024 \mathrm{~g} / \mathrm{m}^{3}$ sulfur compounds that can be found both in the odorant and the natural gas itself. During the tests, the natural gas ran through a primary filter containing $\mathrm{NaA}$ zeolite and then a secondary zinc-oxide-based filter. After the sulfur compounds were removed, the natural gas was dedusted and delivered to a heat exchanger, where the steam was also introduced. The water for steam generation was dosed using a high-accuracy infusion pump AST 510 with a flow rate ranging from 0.001 to $80 \mathrm{ml} / \mathrm{min}$, peak flow power consumption being as low as $60 \mathrm{~W}$ and accuracy of $0.25 \%$. Then, the steam-gas mixture was supplied to a Ni catalyst reformer, where the steam methane reforming occurred at temperatures ranging from 550 to $800^{\circ} \mathrm{C}$. A natural gas water volume ratio of 3 was maintained during the tests in order to prevent soot formation in the reformer. From the reformer, the gas mixture or 'synthesis gas' consisting, basically, of $\mathrm{H}_{2}, \mathrm{H}_{2} \mathrm{O}$ and $\mathrm{CO}$ with small amounts of $\mathrm{CO}_{2}$ and $\mathrm{CH}_{4}$, ran to an anode channel, where the hydrogen and carbon monoxide oxidized to form $\mathrm{H}_{2} \mathrm{O}$ and $\mathrm{CO}_{2}$, correspondingly.

Apart from the reformer, after it was dedusted and preheated in a heat exchanger using the waste heat from the post-combustion burner, the air was sent to the anode channel. Since the SOFC batteries produced direct current, and the consumer required alternating cur-

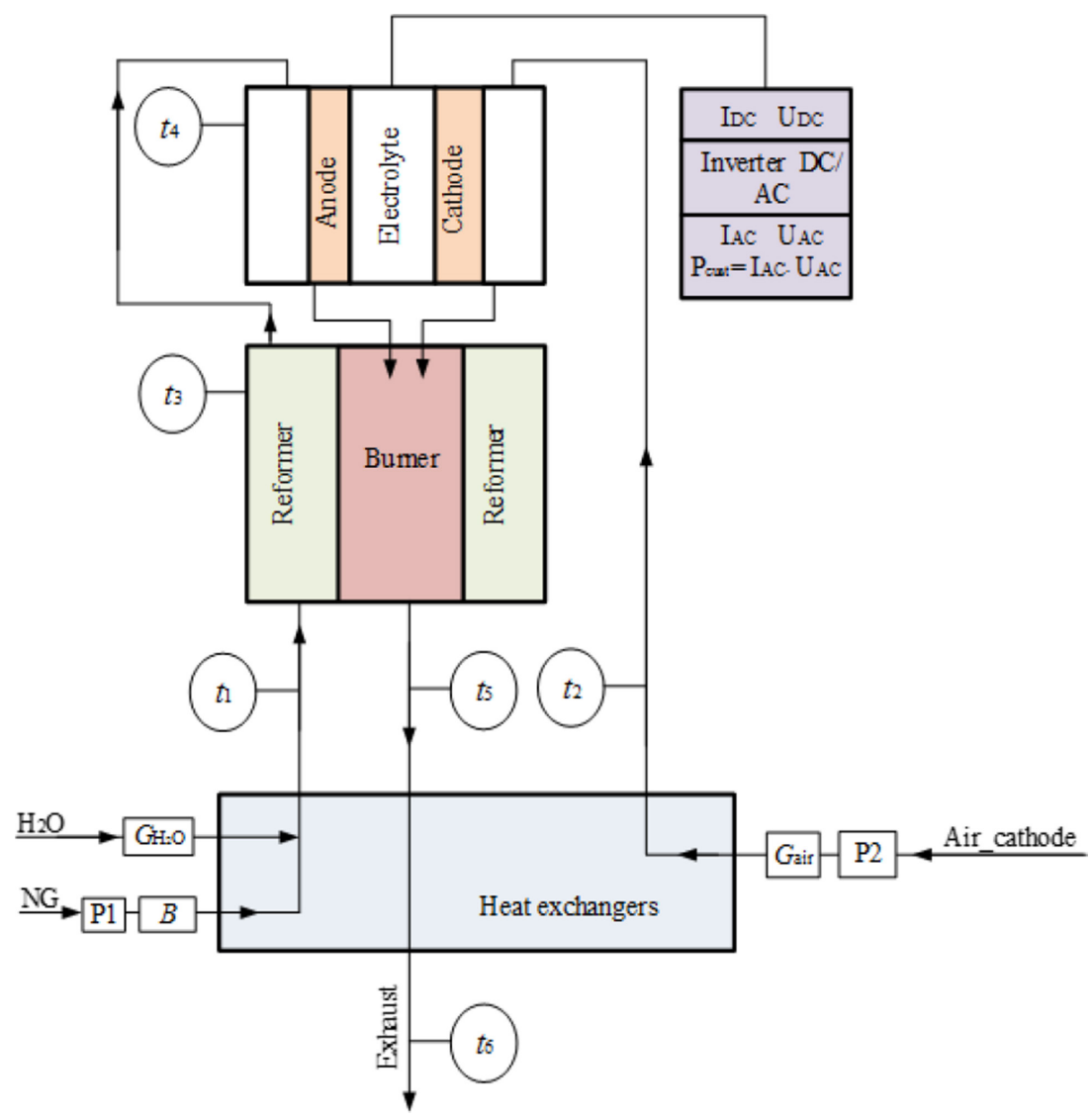

Figure 1: Diagram of a $5 \mathrm{~kW}$ SOFC-based power plant. 
rent (AC), an inverter with efficiency up to $95 \%$ was applied. A $7 \mathrm{~kW}$ lab autotransformer assembly was used as an AC consumer for load dropping and raising. Since they contained combustible components, the reaction products leaving the anode channel were supplied to a catalytic burner for their complete catalytic oxidation using the vitiated air from the cathode in order to ensure acceptable parameters. The combustion heat was transferred to the steam reformer. The reformer and the burner were integrated into a pipe-in-pipe system that helped reduce the heat loss and improve the efficiency of the plant [2]. The temperature was measured using $\mathrm{Cr} / \mathrm{Al}$ thermocouples located at (Fig. 1): the steam-gas mixture outlet of the heat exchanger $\left(t_{1}\right)$, the air outlet of the heat exchanger $\left(t_{2}\right)$, the reformer outlet $\left(t_{3}\right)$, the SOFC stacks outlet $\left(t_{4}\right)$, the burner outlet $\left(t_{5}\right)$, and downstream of the heat exchanger $\left(t_{6}\right)$. The pressure of the natural gas $\left(\mathrm{P}_{1}\right)$ and of the air $\left(\mathrm{P}_{2}\right)$ was registered at the heat exchanger outlet. The flow rates of the water $\left(\mathrm{G}_{\mathrm{H} 2 \mathrm{O}}\right)$, natural gas $(B)$ and cathode air $\left(\mathrm{G}_{\text {air }}\right)$ were also measured.

\section{EXPERIMENTAL FINDINGS}

Each mode was considered as steady-state, if any changes in characteristics remained within $2 \%-4 \%$, for $30 \mathrm{~min}$. The description of the modes is given in Table 1 .

Parameters achieved in the tests are shown in Table 2.

An industrial waste gas analyzer of OPTOGAZ-500 type was used to measure the gas composition. The following components were analyzed: $\mathrm{CO}_{2}, \mathrm{CO}, \mathrm{CH}_{\mathrm{x}}, \mathrm{NO}$, ppm. The probe was arranged in the drain pipe underneath the plant; it was removed after the measurements were taken. The gas sample was dried in a $40 \mathrm{~mm}$ layer of silica gel placed in a small plastic vessel upstream of the gas analyzer. The waste gas samples were taken at the beginning, in the middle and at the end of each mode, in total a duration of $12 \mathrm{~min}$.

Table 1: Description of the power plant test modes.

\begin{tabular}{lcccc}
\hline Mode & $\begin{array}{c}\text { Utilization } \\
(\%)\end{array}$ & $\begin{array}{c}\text { Average power, AC, } \\
\text { kVA }\end{array}$ & $\begin{array}{c}\text { Duration, } \\
\text { min }\end{array}$ & $\begin{array}{c}\text { Current supplied to } \\
\text { consumer V/A }\end{array}$ \\
\hline Mode 1 & 40 & 2 & 245 & $222 / 8.8$ \\
Mode 2 & 60 & 3 & 250 & $223 / 13.4$ \\
Mode 3 & 90 & 4.4 & 248 & $223 / 19.9$ \\
Mode 4 & 110 & 5.3 & 300 & $223 / 24.1$ \\
\hline
\end{tabular}

Table 2: Parameters achieved in the tests.

\begin{tabular}{cccccccccc}
\hline Mode & $\begin{array}{c}G_{\mathrm{H} 2 \mathrm{O}}, \\
\mathrm{ml} / \mathrm{min}\end{array}$ & $B, 1 / \mathrm{min}$ & $\begin{array}{c}G \text { air, } \\
\mathrm{l} / \mathrm{min}\end{array}$ & $\mathrm{t}_{1},{ }^{\circ} \mathrm{C}$ & $\mathrm{t}_{2},{ }^{\circ} \mathrm{C}$ & $\mathrm{t}_{3},{ }^{\circ} \mathrm{C}$ & $\mathrm{t}_{4},{ }^{\circ} \mathrm{C}$ & $\mathrm{t}_{5},{ }^{\circ} \mathrm{C}$ & $\mathrm{t}_{6},{ }^{\circ} \mathrm{C}$ \\
\hline 1 & 12 & 5 & 123 & 703 & 669 & 824 & 690 & 918 & 228 \\
2 & 24 & 10 & 128 & 620 & 581 & 759 & 713 & 748 & 219 \\
3 & 36 & 14.9 & 150 & 563 & 552 & 703 & 748 & 981 & 180 \\
4 & 48 & 20 & 185 & 561 & 543 & 871 & 783 & 1053 & 154 \\
\hline
\end{tabular}


The composition of the combustion products, on dry gas basis, was as follows: $\mathrm{CO}_{2}=3.8 \%$; $\mathrm{CO}=191 \mathrm{ppm} ; \mathrm{NO}_{\mathrm{x}}=2.7 \mathrm{ppm}$.

\section{COMPARISON BETWEEN THE EXPERIMENTAL FINDINGS AND CALCULATED DATA}

The mass and heat balances of the main components of the system were analyzed to calculate the basic parameters. The sum of the mass flows of the water and natural gas represent the synthesis gas flow rate, $\mathrm{kg} / \mathrm{s}$.

$$
B_{\mathrm{ng}}+\mathrm{G}_{\mathrm{H}_{2} \mathrm{O}}=\mathrm{G}_{\mathrm{sg}} \text {. }
$$

The waste gas flow rate is a sum of the mass flows of the synthesis gas produced in the reformer and the air supplied to the anode channel of the fuel batteries.

$$
\mathrm{G}_{\mathrm{sg}}+\mathrm{G}_{\mathrm{air}}=\mathrm{G}_{\mathrm{e}} \text {. }
$$

The heat balance of the electrochemical part of the power plant is therefore:

$$
Q_{s}+L H V \cdot B=N+Q_{2}+Q_{5} .
$$

The sensible heat introduced to the fuel stack is a composite of the sensible heat of the air, natural gas and water. Since, in the experiment, the temperature of the air and natural gas was about $-10^{\circ} \mathrm{C}$, and of the water $+20^{\circ} \mathrm{C}$, the sensible heat was less than $0.5 \%$ heat value of the natural gas. Hence, it can be ignored in the analysis.

The efficiency of an electrochemical generator is typically found using a calculation of its thermodynamic conversion factor [3, 4].

$$
\eta_{\mathrm{T}}=-n F E_{e} / \Delta \mathrm{H}
$$

Molecules of hydrogen are smaller than those of $\mathrm{CO}$ and $\mathrm{CH}_{4}$, so they can more easily diffuse through the porous anode layer and more actively react with the oxygen ions. Because of this, the reaction $\mathrm{H}_{2}+\mathrm{O}^{2}=\mathrm{H}_{2} \mathrm{O}+2 e^{-}$is the basic current-conducting reaction, the percentage of electromotive force contributed by the reaction $\mathrm{CO}+\mathrm{O}^{2}=\mathrm{CO}_{2}+2 \mathrm{e}^{-}$is estimated to be $1 \%$, and it is often ignored in calculations [5]. Two electrons emerge as a result of the hydrogen oxidation reaction; hence, $n_{e}=2$. Therefore, the electromotive force (EMF) for the water-steam formation reaction can be calculated from Formula (4) which, with regard to the above, can be written as follows:

$$
E_{e}=E_{e}^{0}+\left(\frac{R \mathrm{~T}}{2 \mathrm{~F}}\right) \ln \left(\frac{p_{\mathrm{H}_{2}, i} \cdot p_{\mathrm{O}_{2}, i}^{0,5}}{p_{\mathrm{H}_{2} \mathrm{O}, i}}\right) \text {. }
$$

For the purpose of calculation of EMF, Kelvin temperature $t_{4}$ was inserted in eqn (5), as well as the calculated partial pressure of the mixture components in the anode channel.

The thermodynamic calculation of the efficiency seems the simplest approach, but it leaves out the polarization loss in fuel cells, losses with exhaust gases and losses through the thermal insulation occurring during the operation of SOFC systems, which leads to an increase in the characteristics (Fig. 2).

In order to ensure accuracy that is acceptable in real life, the electrical efficiency of SOFCtype electrochemical generators can be calculated, on the basis of the achieved electric output and the measured flow rate of the natural gas, by the formula:

$$
\eta=N_{D C} /(B \cdot \mathrm{LHV}) \text {. }
$$


Figure 2 shows the efficiency calculated as a function of the electric current of the electrochemical generator. The efficiency of a fuel cell considerably decreases with the current, which can be explained by higher polarization loss [6].

In the steam reformer, which is part of the electrochemical generator, methane reforming reactions occurred, followed by the oxidation of the synthesis gas, both in the fuel cells and in the catalytic burner. Ultimately, the effective reaction can be described as an oxidation reaction between the natural gas and the air, since the water introduced in the fuel cell is transferred into the combustion products.

The theoretical air, composition of the combustion products, and the excess air ratio can be calculated using traditional equations [7]. As the output of the electrochemical generator rises and, consequently, the natural gas flow rate increases (with the air flow rate being almost constant), the excess air ratio approaches 1 (Fig. 3).

Since the solid oxide fuel cells use the air for both oxidation of the fuel and cooling of the SOFC stack, the normal excess air ratio in this case will be within 2-4, depending on the operational task and time. The formula for calculating the excess air ratio from [7] does not account for oxygen, which was fed in a bound form to the steam reformer.

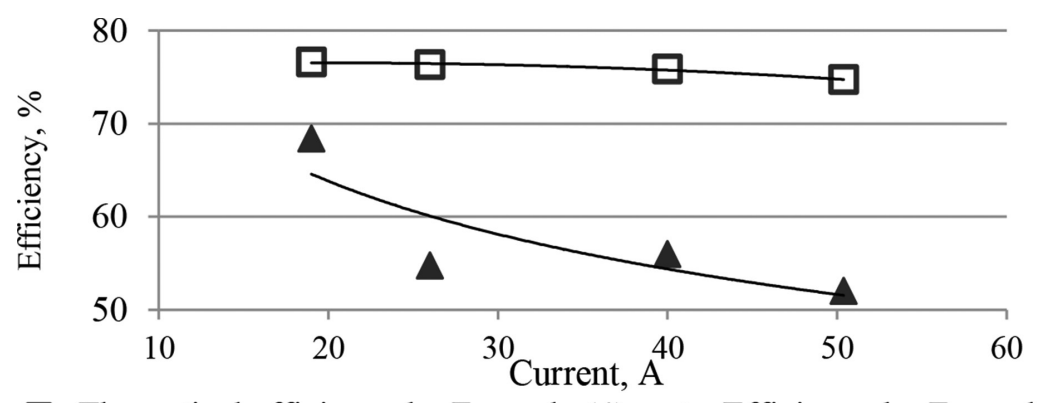

$\square$-Theoretical efficiency by Formula (4)

$\Delta$-Efficiency by Formula (6)

Figure 2: Calculation of efficiency as function of electric current.

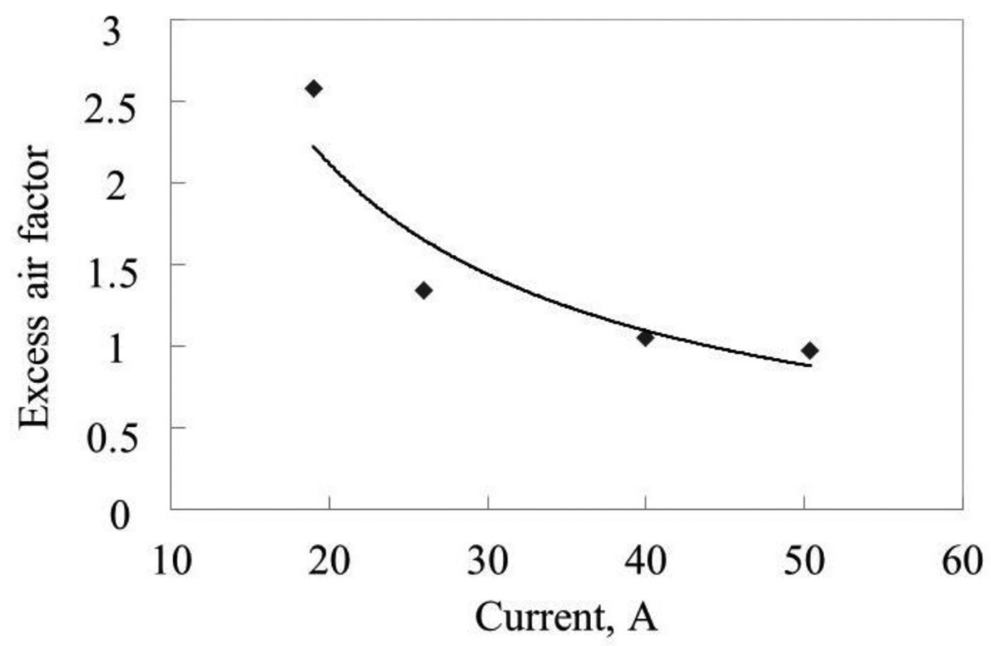

Figure 3: Excess air ratio as function of fuel cell current. 
As the excess air decreases, the $\mathrm{CO}_{2}$ concentration rises, because the combustion products become less diluted with air, and the oxygen concentration declines. As the fuel flow rate rises, and the water flow rate proportionally increases, with the air flow rate being almost constant, the water-steam concentration of the combustion products, naturally, rises. Consequently, the nitrogen concentration decreases. In Mode 1 , the calculated value of $\mathrm{CO}_{2}$ concentration was $4.2 \%$ and the registered value, $3.8 \%$. Since the absolute accuracy of the OPTOGAZ gas analyzer in $\mathrm{CO}_{2}$ measurements is $0.6 \%$, the measured and calculated values are in agreement, given the accuracy of the measurement instrument.

As the consumption of natural gas decreases, the waste-gas heat loss $\left(\mathrm{q}_{2}\right)$ rises (Fig. 4) because of the increase in both excess air and waste gas temperature. However, total heat loss through thermal insulation $\left(\mathrm{q}_{5}\right)$ drops. The heat loss from water evaporation $\left(\mathbf{q}_{\mathrm{H}_{2} \mathrm{O}}\right)$ in the heat exchanger will be permanent because the oxidant flow rate is constant.

In the calculation of the equilibrium composition of the reforming products, the natural gas water mole discharge ratio was $1: 3$, and the reformer outlet temperature $t_{3}$ was taken as a basic temperature.

The composition was calculated in accordance with simplified formulas described in [8]. The assumption was that the mixture components used in the reforming cycle were ideal gases, their volume ratios being $r_{\mathrm{H}_{4}}=1 /(1+3)=0.25, r_{\mathrm{H}_{2} \mathrm{O}}=3 /(1+3)=0.75$. Since the oxidizer is part of the initial fuel, for the purpose of calculations, $\alpha=0$. The results obtained with the simplified procedure were compared with the methods described in [9], formulas from [10] and using the Gaseq software package. The calculation data are summarized in Table 3.

It is observed from the calculation data that the suggested procedure [8] for Modes 1 and 4 gives the same results as the methods in $[9,10]$ and the Gaseq package. Since in Modes 2 and 3 , the temperature is below $800^{\circ} \mathrm{C}$, the results produced by the suggested simplified approach differ slightly from the precise calculations; specifically, the $\mathrm{CO}_{2}$ value is $16 \%$ lower, and $\mathrm{CO}, 9 \%$ higher with the suggested method.

As the temperature increases from $700^{\circ} \mathrm{C}$ to $870^{\circ} \mathrm{C}$, the hydrogen concentration slightly decreases (Table 3); however, the carbon oxide concentration rises and the methane

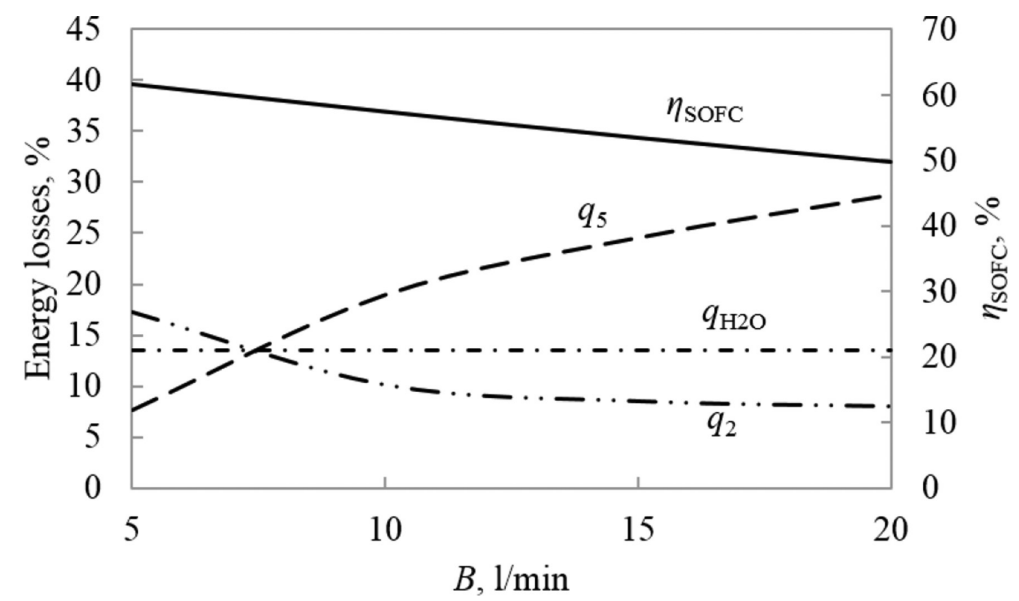

Figure 4: Waste-gas heat loss $\left(\mathrm{q}_{2}\right)$, total heat loss through thermal insulation $\left(\mathrm{q}_{5}\right)$, SOFC efficiency $\left(\eta_{\text {SOFC }}\right)$, heat loss from water evaporation $\left(\mathbf{q}_{\mathrm{H}_{2} \mathrm{O}}\right)$ as function of natural gas consumption. 
Table 3: Results of the calculation of the equilibrium composition for the temperature range used in the tests of the steam reformer plant.

\begin{tabular}{|c|c|c|c|c|c|c|c|c|c|}
\hline \multirow{3}{*}{$\begin{array}{l}\text { Synthesis gas } \\
\text { components }\end{array}$} & \multicolumn{4}{|l|}{ Mode 1} & \multicolumn{5}{|c|}{ Mode 2} \\
\hline & \multicolumn{4}{|l|}{$824^{\circ} \mathrm{C}$} & \multicolumn{5}{|c|}{$759^{\circ} \mathrm{C}$} \\
\hline & [8] & \multicolumn{2}{|l|}{ [9] } & Gaseq & \multicolumn{2}{|c|}{ [10] } & {$[8]$} & [9] & Gaseq \\
\hline $\mathrm{CO}_{2}, \%$ & 5.5 & \multicolumn{2}{|l|}{5.5} & 5.56 & \multicolumn{2}{|l|}{6.3} & 5.3 & 6.3 & 6.3 \\
\hline $\mathrm{CO}, \%$ & 11.1 & \multicolumn{2}{|c|}{11.1} & 11.09 & \multicolumn{2}{|c|}{10.4} & 11.3 & 10.3 & 10.3 \\
\hline $\mathrm{H}_{2} \mathrm{O}, . \%$ & 27.8 & \multicolumn{2}{|c|}{27.8} & 27.81 & \multicolumn{2}{|c|}{27.1} & 27.3 & 27.2 & 27.2 \\
\hline $\mathrm{H}_{2}, \%$ & 55.5 & \multicolumn{2}{|c|}{55.5} & 55.52 & \multicolumn{2}{|c|}{56.3} & 56.0 & 56.1 & 56.1 \\
\hline $\mathrm{CH}_{4}, \%$ & 0.02 & \multicolumn{2}{|c|}{0.02} & 0.02 & \multicolumn{2}{|l|}{0.1} & & 0.1 & 0.1 \\
\hline \multirow{3}{*}{$\begin{array}{l}\text { Synthesis gas } \\
\text { components }\end{array}$} & \multicolumn{4}{|l|}{ Mode 3} & \multicolumn{4}{|c|}{ Mode 4} & \\
\hline & $703^{\circ} \mathrm{C}$ & & & & & $871^{\circ}$ & & & \\
\hline & [10] & [8] & [9] & $\mathrm{Ga}$ & seq & [8] & [9] & & seq \\
\hline $\mathrm{CO}_{2}, \%$ & 7.0 & 5.3 & 7.1 & 7.1 & & 5.1 & 5.1 & 5 & \\
\hline $\mathrm{CO}, \%$ & 9.6 & 11.3 & 9.2 & 9.3 & & 11.6 & 11.7 & & .6 \\
\hline $\mathrm{H}_{2} \mathrm{O}, . \%$ & 26.3 & 27.3 & 27.0 & 27. & & 28.3 & 28.3 & & .2 \\
\hline $\mathrm{H}_{2}, \%$ & 57.0 & 56.0 & 56.2 & 56. & & 55.1 & 55.0 & & .1 \\
\hline $\mathrm{CH}_{4}, \%$ & 0.5 & 0.1 & 0.5 & 0.5 & & 0.01 & 0.01 & & 01 \\
\hline
\end{tabular}

equilibrium concentration drops from $0.5 \%$ to $0.01 \%$. Meanwhile, the heat value of the synthesis gas decreases from $7.52 \mathrm{MJ} / \mathrm{m}^{3}$ to $7.41 \mathrm{MJ} / \mathrm{m}^{3}$.

The calculation of the equilibrium composition of the reforming products enabled us to obtain an equation for the resultant reaction of the natural gas reforming as follows:

$$
\mathrm{CH}_{4}+3 \mathrm{H}_{2} \mathrm{O}=m \mathrm{CO}+n \mathrm{CO}_{2}+\mathrm{lH}_{2}+\mathrm{pH}_{2} \mathrm{O}-Q_{k} \text {. }
$$

Depending on temperature $t_{3}$ at the reformer outlet, the stoichiometric coefficients were measured in the following range: $m=0.58-0.7 ; n=0.3-0.42 ; l=3.3-3.41 ; p=1.58-1.7$. The heat, used for the endothermic reaction of the steam reforming, $Q_{k}$, was calculated as a difference between the standard enthalpies of the reaction products and the input materials $[11,12]$, depending on the operation mode of the power plant. It was found to be within 11.8 to $12.5 \mathrm{MJ} / \mathrm{kg}$ of natural gas.

One of the important characteristics of any fuel cell and SOFC stacks is the percentage of fuel, $\varphi_{\text {fuel }}$, that oxidizes there. It can be found using the heat balance equation for such parts of the system as the reformer, SOFC stack, catalytic burner, and heat exchanger.

The heat balance of the reformer: the heat provided by the heat conduction from the burner $Q_{\lambda}$, sensible heat of the superheated steam and hot natural gas are used to ensure the endothermic reaction of the steam methane reforming, heating of the synthesis gas produced in the reforming and, partially on heat losses through thermal insulation of the reformer $\left(q_{5, \text { ref }}\right)$ 


$$
Q_{\lambda}+G_{\mathrm{H}_{2} \mathrm{O}} c_{\mathrm{H}_{2} \mathrm{O}} t_{1}+B c_{n g} t_{1}=G_{s-g} c_{s-g} t_{3}+B Q_{k}+q_{5, \mathrm{ref}} .
$$

The heat balance of the SOFC stack: the sensible heat of the synthesis gas and hot air as well as heat from the oxidation of synthesis gas are used for the DC (direct current) production, for heating of the combustion products and the heat losses through thermal insulation of the SOFC stack $\left(q_{5, \text { stack }}\right)$.

$$
G_{s-g} c_{s-g} t_{3}+G_{\text {air }} c_{\text {air }} t_{2}+\varphi_{\text {fuel }} G_{s-g} Q_{s-g}=N+G_{e} c_{e} t_{4}+q_{5, \text { stack }}
$$

The heat balance of the catalytic burner: the heat, produced in the oxidation of the gas leaving the anode, is used to reheat the combustion products to temperature $t_{5}$ and then, through the heat conduction, for heating the reformer $Q_{\lambda}$.

$$
\left(1-\varphi_{\text {fuel }}\right) \mathrm{G}_{\mathrm{s}-\mathrm{g}} \mathrm{Q}_{\mathrm{s}-\mathrm{g}}=\mathrm{G}_{\mathrm{e}} \mathrm{c}_{\mathrm{e}}\left(\mathrm{t}_{5}-\mathrm{t}_{4}\right)+\mathrm{Q}_{»} .
$$

The heat balance of the heat exchanger: the heat given by the combustion products in the heat exchanger is used for the heating and evaporation of water for the reformer, the heating of the natural gas and air and, partially, for the heat losses through thermal insulation of the heat exchanger $\left(q_{5, h e}\right)$.

$$
G_{e}\left(c_{e} t_{5}-c_{e} t_{6}\right)=B\left(c_{n g} t_{1}-c_{n g} t_{0}\right)+G_{H_{2} O}\left(h_{1}-c_{H_{2} O} t_{0}^{\prime}\right)+G_{a i r}\left(c_{a i r} t_{1}-c_{a i r} t_{0}\right)+q_{5, \text { he }}
$$

This system of equations includes the following unknowns: the heat delivered through the heat conduction to the reformer $Q_{\lambda}$ and the percentage of the oxidized products of the reforming in the fuel stack $\varphi_{\text {fuel }}$, as well as the heat loss sustained by different parts of the fuel stack.

The comparison between the calculation data and experimental findings allowed us to find the percentage of the oxidized synthesis gas in the fuel stacks, which, in accordance with the calculations, heavily depends on the fuel stack load (Fig. 5). The unreacted part of the synthesis gas from the anode channel oxidizes in the catalytic burner, and the resultant heat is used to ensure the reaction in the reformer and cover the heat loss.

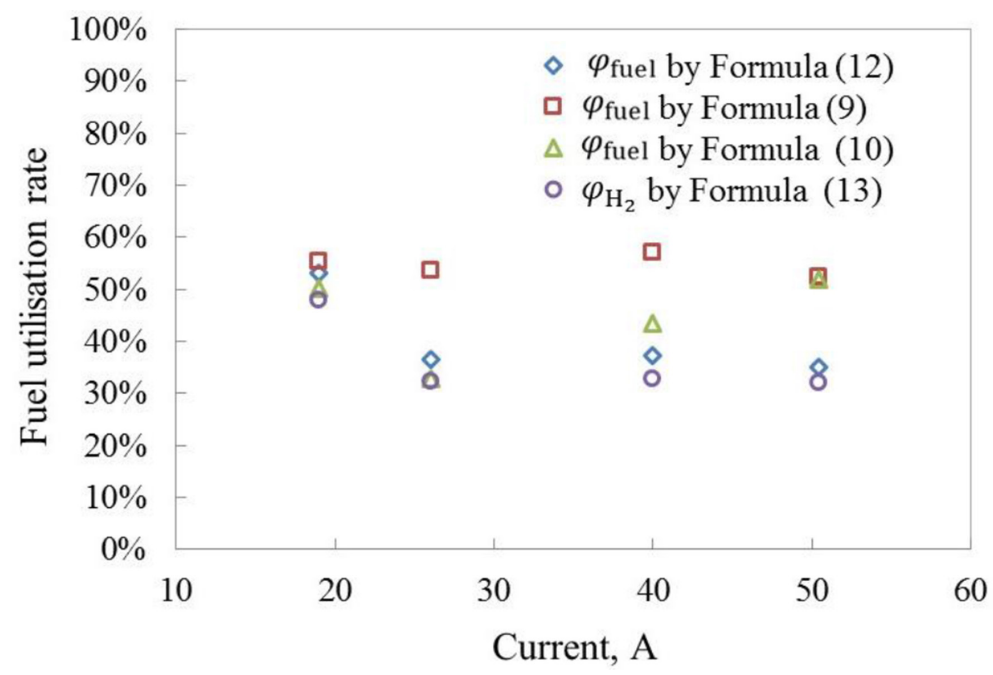

Figure 5: Fuel and hydrogen utilization factor versus current. 
The fuel utilization factor for an electrochemical system can also be found by using eqn (12). The latter, in fact, denotes the percentage of the natural gas used to produce the electric current for the given mass flow based on Faraday's law:

$$
\varphi_{\text {fuel }}=\frac{\mathrm{I} \cdot \mathrm{n}_{\text {cells }}}{\mathrm{n}_{\text {stack }} \cdot \mathrm{z}_{\mathrm{ng}} \cdot \mathrm{F} \cdot \mathrm{n}_{\mathrm{ng}}},
$$

Figure 5 shows the fuel utilization factor versus the power utilization. It is observed from Fig. 5 that for Modes 1-3, with utilization of 40 to $90 \%$, eqns (12) and (10) produce almost the same result. A marked difference is seen for Mode 4, where the calculation according to Formula (10) from the catalytic burner balance produces the same result as Formula (9) for the SOFC battery balance, while Formula (12) gives a considerably lower result. In Mode 4, for the established current and flow of the natural gas, only $35 \%$ of fuel was used to produce the electric current, and about $40 \%$ was used to maintain the endothermic reaction in the reformer; however, from the point of the heat balance of the burner and the fuel stack, this percentage is as high as $52 \%$.

The utilization of hydrogen in the electric current production can be determined from Faraday's law.

$$
\varphi_{\mathrm{H}_{2}}=\frac{\mathrm{I} \cdot \mathrm{n}_{\text {cells }}}{\mathrm{n}_{\text {stack }} \cdot \mathrm{z}_{\mathrm{H} 2} \cdot \mathrm{F} \cdot \mathrm{n}_{\mathrm{sg}} \cdot \mathrm{H}_{2}},
$$

The difference between $\varphi_{\mathrm{H}_{2}}$ and $\varphi_{\text {fuel }}$ was due to the fact that Formula (13) left out the effect of $\mathrm{CO}$, which the synthesis gas contained.

\section{CONCLUSIONS}

1. The tests of the $5 \mathrm{~kW}$ SOFC power plant enabled us to establish the dependence of the efficiency, excess air ratio and heat loss on the power utilization.

2. The comparison between the calculation data and experimental findings led to the resultant reaction occurring in the reformer.

3. The analysis of the heat balance equations made it possible to determine the percentage of the synthesis gas oxidized in the SOFC stack.

4. Based on the efficiency of the electrochemical generator, the most efficient operation modes for the power plant were found. With the $40 \%$ utilization, the efficiency of the electrochemical generator was as high as $70 \%$. Such modes are preferable during operation as they help extend the life of power plants. The modes with $60 \%$ and $90 \%$ rated power utilization seem to be the optimum for longer and more reliable operation of power plants.

5. The simplified calculation procedure for the synthesis gas composition can be used at temperatures higher than $800^{\circ} \mathrm{C}$ with acceptable accuracy. However, the calculation error will be higher for lower temperatures.

\section{ACKNOWLEDGMENTS}

The authors would like to express their thanks to all partners who have contributed to the study. The authors would also like to acknowledge Ningbo SOFCMAN Electric Power Technology Co. Ltd, from China, for help in conducting the experiments. 


\section{REFERENCES}

[1] Baskakov, A.P. \& Volkova, Y.V., Physics and Chemistry of Thermal Processes: Textbook, Moscow: Teplotehnik, 2013.

[2] Chang, T.G., Lee, S.M., Ahn, K.Y. \& Kim, Y., An experimental study on the reaction characteristics of a coupled reactor with a catalytic combustor and a steam reformer for SOFC systems. International Journal of Hydrogen Energy, 37, pp. 3234-3241, 2012. http://dx.doi.org/10.1016/j.ijhydene.2011.11.076

[3] Korovin, N.V., Sedlov, A.S., Slavnov, Yu.A. \& Burov, V.D., Calculating the efficiency of a hybrid power station based on a high-temperature power cell. Teploenergetika. 2,pp. 49-53, 2007.

[4] Lykova, S.A., High-efficiency hybrid power facilities based on fuel cells. Teploenergetika, 15, pp. 50-55, 2002.

[5] Korovin, N.A., Fuel Cells and Electrochemical Power Facilities, Moscow: MPEI, p. 280, 2005.

[6] Kasilova, E.V., Analytical and theoretical study of transfer processes in a solid oxide fuel cell: Candidate dissertation in Engineering Science. Moscow: MPEI, 2015.

[7] Boiler Thermal Design (normative method). 3rd edn., revised and enlarged. St. Petersburg: NPO CKTI, 1998.

[8] Baskakov, A.P., Volkova, Yu.V. \& Plotnikov, N.S., Optimum rate of chemical regeneration in solid oxide fuel cells. Engineering and Physics Journal, 78(4), pp. 741-750.

[9] Leibush, A.G. (ed), Production of Process Gas for Synthesizing NH3 and Methanol from Hydrocarbon Gases, Moscow: Himiya, 1971.

[10] Baskakov, A.P., Heating and Cooling Metals in a Bubbling Layer, Moscow: Metallurgiya, 1974.

[11] Ravdel, K.P. \& Mischenko, A.A. (eds), Critical Tables. Quick Reference Book, 7th edn., Leningrad: Himiya, 1974.

[12] Bogdanov, S.N., Burtsev, S.I., Ivanov, O.P. \& Kupriyanova, A.V. Refrigeration Appliances and Engineering. Air Conditioning. Properties of Substances: Reference Book, 4th edn., revised and enlarged. St. Petersburg, 1999. 